\title{
O-chain expression in the rough Brucella melitensis strain B115: induction of O-polysaccharide-specific monoclonal antibodies and intracellular localization demonstrated by immunoelectron microscopy
}

\author{
Axel Cloeckaert, ${ }^{1 *}$ Michel S. Zygmunt, ${ }^{2}$ Jean-Claude Nicolle, ${ }^{3}$ Gerard Dubray ${ }^{2}$ and \\ JOSEPH N. LIMET ${ }^{4}$ \\ ${ }^{1}$ Unit of Experimental Medicine, Catholic University of Louvain, 75 avenue Hippocrate, B-1200 Brussels, Belgium \\ 2Institut National de la Recherche Agronomique, Laboratoire de Pathologie Infectieuse et Immunologie, \\ 37380 Nouzilly, France \\ ${ }^{3}$ Institut National de la Recherche Agronomique, Laboratoire de Physiologie de la Reproduction, 37380 Nouzilly, France \\ ${ }^{4}$ Facultés Universitaires Notre Dame de la Paix, 61 rue de Bruxelles, 5000 Namur, Belgium
}

(Received 25 November 1991; revised 27 January 1992; accepted 19 February 1992)

\begin{abstract}
Spleen cells from mice infected with the rough Brucella melitensis strain B115 were fused with NSO myeloma cells. Hybridoma supernatants were screened in ELISA with cell walls $(C W)$, sonicated cell extracts (CE) and rough lipopolysaccharide (R-LPS) of B. melitensis strain B115 and whole B. melitensis B115 cells. Surprisingly, 22 monoclonal antibodies (mAbs) reacting in ELISA with both CW and CE but not with R-LPS and bacterial cells were shown by immunoblot analysis and ELISA to react with smooth lipopolysaccharide (S-LPS). These mAbs also reacted in ELISA with O polysaccharides (OPS) from the smooth Brucella abortus strain 99 and the smooth B. melitensis strain 16M and thus recognize epitopes present on the O-chain. Proteinase K LPS preparations from B. melitensis B115 analysed by immunoblotting with one mAb (12G12) recognizing S-LPS of both $A$ and $M$ specificity displayed the typical S-LPS high-molecular-mass ladder pattern but no S-LPS was detected in the phenol/water/chloroform/light petroleum LPS preparation of the same strain. mAb 12G12, specific for S-LPS, and a mAb (A68/03F03/D05) specific for R-LPS were used to localize the O-chain and R-LPS expressed in B. melitensis strain B115 by immunoelectron microscopy. Immunogold labelling was observed at the surface of B. melitensis B115 cells with the anti-R-LPS mAb but not with the anti-S-LPS mAb. In ultrathin sections, immunogold labelling with the S-LPS specific mAb was observed in the cytoplasm and in the periphery of the cytoplasm, probably at the cytoplasmic membrane. Immunogold labelling with the R-LPS specific mAb was observed at the outer membrane, outside the cells and on R-LPS vesicles. These results indicate that O-chain expressed in the rough $B$. melitensis strain B115 is immunogenic in mice, not exposed at the cell surface but present in the cytoplasm and most probably at the cytoplasmic membrane.
\end{abstract}

\section{Introduction}

The S-LPS of smooth-type Brucella spp. contains two distinct antigenic determinants designated $\mathbf{A}$ and $\mathbf{M}$ (Bundle et al., 1987, 1989; Diaz et al., 1968; Douglas \& Palmer, 1988; Meikle et al., 1989; Wilson \& Miles, 1932). The relative amounts of the two determinants vary among the smooth Brucella strains, and the determinants

* Author for correspondence. Tel. 276474 30; fax 27647571 .

Abbreviations: CE, sonicated cell extract; CP, cytoplasmic fraction; $\mathrm{CW}$, cell walls; OPS, O polysaccharide; RAM, rabbit anti-mouse immunoglobulin antiserum; R-LPS and S-LPS, rough and smooth lipopolysaccharide. are absent on the rough strains, which lack O-chain (Alton et al., 1988). mAbs to S-LPS of Brucella spp. have been reported with specificity for the A-LPS determinant and the M-LPS determinant (Bundle et al., 1989; Douglas \& Palmer, 1988; Palmer \& Douglas, 1989). Other mAbs were found to react equally with S-LPS of both A- and M-dominant Brucella strains, some of them being specific to Brucella and others reacting also with Yersinia enterocolitica O:9 S-LPS (Douglas \& Palmer, 1988; Palmer \& Douglas, 1989). They were designated as specific for common (C) S-LPS determinants.

The rough Brucella melitensis strain B115, believed to be devoid of S-LPS or O-chain contamination, has been 
used for preparing cytoplasmic antigens (Jones et al., 1973; Zygmunt et al., 1990) to study the immune response and also for extraction by the trichloroacetic acid method (Diaz et al., 1972, 1979, 1983; FernandezLago et al., 1982; Moreno et al., 1981) of a polysaccharide fraction called polysaccharide B. Interest in Brucella polysaccharide $B$ fraction stems in large part from its reported efficacy in tests that differentiate vaccinated from naturally infected cattle (Diaz et al., 1979, 1981, 1983). Recently, polysaccharide B fraction from smooth cells of $B$. melitensis $16 \mathrm{M}$, produced by the trichloroacetic acid extraction method used for B. melitensis B115, was found to be composed of O polysaccharide (OPS) (up to $20 \%$ by weight) and cyclic D-glucan, serologically inactive, which was regarded as polysaccharide B (Bundle et al., 1987, 1988). In fact, polysaccharide B fraction from $B$. melitensis $B 115$ rough cells was not really analysed. Nevertheless, Jones et al. (1973) showed that injection of living or killed cells of strain B115 into rabbits produced low-titre agglutinins to smooth cells, but they were unable to extract S-LPS from strain B115. Furthermore, whole cells of B. melitensis B115 were not able to absorb anti-smooth agglutinins from sera (Diaz et al., 1968).

We have reinvestigated the $\mathrm{O}$-chain expression in $B$. melitensis B115 rough cells by using (1) hybridoma technology - characterization of one OPS-specific mAb induced by infecting mice with this rough strain, and (2) electron microscopic localization of the O-chain expressed in this strain by immunogold labelling using this O-polysaccharide-specific mAb.

\section{Methods}

Bacterial strains. The rough (R) Brucella melitensis strain B115 and the smooth (S) strains B. melitensis $16 \mathrm{M}$ and B. abortus 99 were obtained from the Institut National de la Recherche Agronomique, Laboratoire de Pathologie Infectieuse et Immunologie, Nouzilly, Tours, France. Purity and $R$ and $S$ phenotypes were clearly established by direct microscopic observation of colonies by obliquely reflected light and staining of $\mathrm{R}$ colonies with crystal violet (Alton et al., 1988). The $\mathrm{R}$ phenotype of $B$. melitensis strain B115 has been found stable over a period of 18 years (Alton et al., 1988; Jones et al., 1973).

Whole bacterial cells used for binding studies. Cultures were grown at $37^{\circ} \mathrm{C}$ for $48 \mathrm{~h}$ on trypticase soy agar (BioMérieux, Marcy-l'Etoile, France) slants supplemented with $0 \cdot 1 \%(\mathrm{w} / \mathrm{v})$ yeast extract (Difco). Cells were harvested by gentle agitation in sterile distilled water. Purity and phase (smooth, $\mathrm{S}$; or rough, $\mathrm{R}$ ) were checked using standard procedures (Alton et al., 1988). Dilutions were made in phosphatebuffered saline containing $0.5 \%(\mathrm{v} / \mathrm{v})$ Tween 80 and the number of cells was determined by optical density measurements at $600 \mathrm{~nm}$ in a spectrophotometer $\left(\mathrm{OD}_{600}=0.165\right.$ for $10^{9} \mathrm{cells} \mathrm{ml}^{-1}$ for a $1 \mathrm{~cm}$ light path). Cells were killed by addition of a $5 \%(\mathrm{v} / \mathrm{v})$ peracetic acid solution (Aldrich) $\left(20 \mu \mathrm{ml}^{-1}\right.$ to $10^{10}$ cells $\left.\mathrm{ml}^{-1}\right)$ and incubated overnight at room temperature. Before use, killing was checked by taking $1 \mathrm{ml}$ of each cell suspension and, after three washes in sterile distilled water, $0.2 \mathrm{ml}$ was spread on Petri dishes containing the culture medium.
Bacterial fractions. Cell walls (CW) from B. melitensis $\mathrm{B} 115$ were isolated as previously described (Dubray \& Charriaut, 1983). Briefly, cells were inactivated by heating at $65^{\circ} \mathrm{C}$ for $1 \mathrm{~h}$ and broken with glass beads in a Braun MSK homogenizer or a Dyno-Mill apparatus (W.A. Bachofen, Basel, Switzerland). Crude $\mathrm{CW}$ were recovered by centrifugation (at $53000 \mathrm{~g}, 4^{\circ} \mathrm{C}$ for $1.5 \mathrm{~h}$ ). $\mathrm{CW}$ were obtained by treating crude CW with $1 \%(\mathrm{w} / \mathrm{v})$ Triton $\mathrm{X}-100$ in $0.2 \mathrm{M}-\mathrm{NaCl}, 0.01 \mathrm{M}-\mathrm{MgCl}_{2}$ for 30 min at $20^{\circ} \mathrm{C}$, washed six times in distilled water and lyophilized.

Cell extracts (CE) of $B$. melitensis B115 were obtained by ultrasonication. Cells were inactivated by heat at $65^{\circ} \mathrm{C}$ for $1 \mathrm{~h}$, washed three times in $0.9 \% \mathrm{NaCl}$ and ultrasonicated for $15 \mathrm{~min}$ in $1 \mathrm{mM}$ EDTA, $30 \mathrm{~mm}$-Tris $\mathrm{pH} 8$. The ultrasonicated cells were then centrifuged for $10 \mathrm{~min}$ at $4000 \mathrm{~g}$, and the supernatant was recovered.

Cytoplasmic fraction (CP) of B. melitensis B115 was prepared as described by Zygmunt et al. (1990) by breaking heat-inactivated cells with glass beads in a Dyno-Mill apparatus followed by a first ultrafiltration with hollow-fibre cartridges of $0 \cdot 1 \mu \mathrm{m}$ cut-off (Amicon). The ultrafiltrate was treated with ribonuclease and deoxyribonuclease (Worthington Diagnostics) followed by a second uitrafiltration with hollow-fibre cartridges of $100 \mathrm{kDa}$ cut-off (Amicon). The retentate was centrifuged at $50000 \mathrm{~g}$ for $16 \mathrm{~h}$ and the cleared supernatant (CP) was lyophilized.

LPS fractions. S-LPS fraction of $B$. melitensis $16 \mathrm{M}$ was prepared by the phenol/water method (Leong et al., 1970). R-LPS fraction of $B$. melitensis B115 was obtained by the phenol/water/chloroform/light petroleum method of Galanos et al. (1969). Proteinase-K-digested SLPS fractions of B. melitensis 16M, B. abortus 99 and B. melitensis B1 15 were prepared as described previously (Garin-Bastuji et al., 1990). S-LPS fraction of $B$. melitensis B115 was isolated from CW. S-LPS fractions of $B$. melitensis $16 \mathrm{M}$ and $B$. abortus 99 were isolated from whole smooth bacterial cells. OPS of B. abortus 99 and B. melitensis $16 \mathrm{M}$ was extracted by autoclaving $\mathrm{S}$ cells in $2 \%(\mathrm{v} / \mathrm{v})$ acetic acid $/ 10 \%$ (w/v) $\mathrm{NaCl}$ as described by Jacques et al. (1991). The OPS was purified by high-performance liquid chromatography using a size-exclusion preparative TSK-G-2000-SW $(600 \times 25 \mathrm{~mm})$ column (Zygmunt et al., 1988).

mAbs. The anti-S-LPS and anti-R-LPS mAbs were obtained as described previously (Cloeckaert et al., 1990). Briefly, BALB/c mice were infected by intraperitoneal (i.p.) injection of $10^{9}$ B. melitensis $B 115$ rough cells. After 4 months, the mice were boosted i.p. with $10^{9}$ heatKilled B. melitensis B115 rough cells. Four days after the booster injection, spleen cells were fused with cells of the NSO non-secreting myeloma cell line in a ratio of $5: 1$. After fusion, cells were suspended in selective hypoxanthine-aminopterin-thymidine-containing medium and seeded in 96-well microtitre plates at $5 \times 10^{4}$ splenocytes per well. Anti-Brucella hybridomas were screened by ELISA and cloned by the limiting dilution technique. Specificity was determined by immunoblot analysis and ELISA using CW, CE and R-LPS of B. melitensis B115 and S-LPS of B. melitensis $16 \mathrm{M}$ and B. abortus 99 . Ascitic fluids were prepared in BALB/c mice by the method of Limet et al. (1987).

Reagents. These were as follows. Glycine-buffered Saline (GBS): $0 \cdot 17 \mathrm{M}-\mathrm{NaCl}, 0 \cdot 1 \mathrm{M}$-glycine and $6 \mathrm{mM}^{-\mathrm{NaN}_{3}}$; pH 9.2. GBS-EDTA-Tw: GBS containing $50 \mathrm{~mm}$-EDTA and $0 \cdot 1 \%$ Tween 80 ; final pH 9.2. Citrate/phosphate buffer: $0.051 \mathrm{M}-\mathrm{Na}_{2} \mathrm{HPO}_{4}, 0.024 \mathrm{M}$-citric acid; pH 5. NaCl-Tw : $0.15 \mathrm{M}-\mathrm{NaCl}, 0.01 \%$ Tween 20 . Tris-buffered saline (TBS): $0.15 \mathrm{M}-\mathrm{NaCl}, 10 \mathrm{~mm}-\mathrm{Tris} / \mathrm{HCl} ; \mathrm{pH} 7 \cdot 5$. Tw-TBS: TBS containing $0.05 \%(v / v)$ Tween 20 . TBS-3\% BSA: TBS containing $3 \%(w / v)$ bovine serum albumin. Tw-TBS- $1 \%$ BSA: Tw-TBS containing $1 \%$ (w/v) BSA. PBS-Tw: phosphate-buffered saline (PBS; $0.15 \mathrm{M}-\mathrm{NaCl}$, $0.01 \mathrm{M}$-sodium phosphate, $\mathrm{pH} 7.5$ ) containing $0.05 \%$ Tween 20 . PBS$3 \%$ BSA: PBS containing $3 \%(w / v)$ BSA.

Antisera. Rabbit anti-mouse immunoglobulin antiserum (RAM) was produced by repeated intradermal injections of $100 \mu \mathrm{g}$ of mouse IgG. 
After three injections at $15 \mathrm{~d}$ intervals, the rabbits were bled. Each month, boosters of $100 \mu \mathrm{g}$ were repeated and followed by bleeding $10 \mathrm{~d}$ later. The best bleedings, as determined by latex agglutination immunoassay (Limet et al., 1988) using latex particles coated with mouse IgG, were pooled.

Rabbit anti-Brucella antiserum was produced by repeated intradermal injections of $10^{9}$ killed cells of $B$. abortus $45 / 20$ (R). After three injections at $15 \mathrm{~d}$ intervals, the rabbits were bled. The bleedings were tested by ELISA using $B$. abortus $45 / 20$ (R) cells as antigen. Immunoglobulin fraction (Ig) was obtained by $\left(\mathrm{NH}_{4}\right)_{2} \mathrm{SO}_{4}$ precipitation.

Peroxidase conjugation. Protein A (Sigma) was conjugated with horseradish peroxidase (Sigma) using a modification of the method of Nakane \& Kawaoï (1974) as described by Dubray \& Limet (1987). The protein/enzyme ratio was $1: 2$.

ELISA. Supernatants of hybridoma cultures or ascitic fluids were assayed for antibody activity by solid-phase ELISA against antigens coated by overnight incubation at $37^{\circ} \mathrm{C}$ after dilution in fivefolddiluted GBS in water (Voller et al., 1979). The antigens used to coat the plates consisted of CW $\left(20 \mu \mathrm{g} \mathrm{ml}^{-1}\right), \mathrm{CE}$ (diluted 1 in 1000), S-LPS $\left(4 \mu \mathrm{g} \mathrm{ml}^{-1}\right)$, R-LPS $\left(10 \mu \mathrm{g} \mathrm{ml}^{-1}\right)$, OPS $\left(4 \mu \mathrm{g} \mathrm{ml}^{-1}\right)$ and whole bacterial cells $\left(\mathrm{OD}_{600} 1 \cdot 5\right)$. Whole bacterial cells were immobilized on microtitre plates (Greiner-Labortechnic-Stuttgart) by means of rabbit antiBrucella Ig adsorbed at a coating concentration of $10 \mu \mathrm{g} \mathrm{ml}^{-1}$. Hybridoma supernatants were diluted ( 1 in 2 ) in GBS-EDTA-Tw. Binding of the antibodies to CW, CE, S-LPS or R-LPS was revealed by using RAM diluted 1 in 1000 in GBS-EDTA-Tw and peroxidaseconjugated protein A diluted 1 in 1000 in GBS-EDTA-Tw containing $2 \%(\mathrm{v} / \mathrm{v})$ foetal calf serum. Binding to whole bacterial cells was revealed with peroxidase-conjugated goat anti-mouse immunoglobulins (Kierkegaard and Perry Laboratories) diluted 1 in 1000 in GBS-EDTA-Tw containing $2 \%$ foetal calf serum. Excess of reagents between the different incubations were removed by five washings with $\mathrm{NaCl}-\mathrm{Tw} . o-$ Phenylenediamine $(0.4 \%, \mathrm{w} / \mathrm{v})$ and $2 \mathrm{mM}-\mathrm{H}_{2} \mathrm{O}_{2}$ in citrate/phosphate buffer were used to reveal peroxidase activity. The ELISA titres were estimated as the highest dilution giving a difference in absorbance $(492-620 \mathrm{~nm})$ above twice the mean of the corresponding blank values.

Thin-section preparation. The method of thin-section preparation was as described by Lam et al. (1987). Samples were fixed in $1 \mathrm{ml}$ of $2.5 \%$ (v/v) glutaraldehyde in PBS overnight at $4{ }^{\circ} \mathrm{C}$ or in $1 \mathrm{ml} 4 \%(\mathrm{v} / \mathrm{v})$ paraformaldehyde buffered with $0.1 \mathrm{M}$-cacodylate at $\mathrm{pH} 7.25$ for $1 \mathrm{~h}$ at room temperature. After fixation, samples were set in $5 \%(\mathrm{w} / \mathrm{v})$ agarose and washed in buffer. The cores were then dehydrated through a stepwise alcohol series and infiltrated in propylene oxide. The samples were then embedded in Epon 812 resin and cured for $24 \mathrm{~h}$ at $37^{\circ} \mathrm{C}$. Ultrathin sections were obtained by cutting the embedded material with an ultramicrotome (Reichert Jung Ultracut E) and deposited on 200-mesh gold grids.

Immunogold labelling. (i) Whole-mount incubations. A $5 \mu$ sample of cell suspension in water $\left(10^{10}\right.$ bacteria $\left.\mathrm{ml}^{-1}\right)$ was deposited on carbonFormvar-coated 200-mesh copper grids. After being air-dried (about 30 $\mathrm{min}$ ), grids were incubated in the following reagents: PBS-3\% BSA (30 $\min$ at $37^{\circ} \mathrm{C}$ ), ascitic fluid containing the mAb diluted 1 in 50 in PBSTw $\left(2 \mathrm{~h}\right.$ at $\left.37^{\circ} \mathrm{C}\right)$, sheep anti-mouse biotinylated Ig (Amersham) diluted 1 in 200 in PBS-Tw (1 h at room temperature), gold-labelled streptavidin (15 nm) (Amersham) diluted 1 in 20 in PBS-Tw (1 h at room temperature). Washings between incubation periods were performed with $\mathrm{NaCl}-\mathrm{Tw}$. After four washings in $\mathrm{NaCl}-\mathrm{Tw}$ and four washings in distilled water, grids were observed in a transmission electron microscope (Philips CM 10).

(ii) Section incubations. The same procedure as for whole mounts was followed, except that before incubation in PBS-3\% BSA the grids were pretreated in $10 \%(\mathrm{v} / \mathrm{v}) \mathrm{H}_{2} \mathrm{O}_{2}$ in distilled water for $30 \mathrm{~min}$ and then washed in distilled water. After immunogold labelling, the sections were stained with $4 \%(w / v)$ uranyl acetate in water and $0.4 \%$ lead citrate in $0.1 \mathrm{M}-\mathrm{NaOH}$.

(iii) Cell wall incubations. One milligram of B. melitensis $\mathrm{B} 115 \mathrm{CW}$ was incubated in $1 \mathrm{ml}$ of the same reagents as described for whole-mount incubations. Washings between incubation periods were performed with $\mathrm{NaCl}-\mathrm{Tw}$. After immunogold labelling, the $\mathrm{CW}$ were treated as described for thin-section preparation. After sectioning, staining was performed with $4 \%(w / v)$ uranyl acetate in water and $0.4 \%(w / v)$ lead citrate in $0.1 \mathrm{M}-\mathrm{NaOH}$.

Immunoblot techniques. The antigens were separated by SDS-PAGE (Laemmli, 1970), in the 2001 vertical electrophoresis unit (LKBProdukter). After electrophoresis, the antigens were transferred to nitrocellulose by using a Transblot apparatus (Biolyon) at $12 \mathrm{~V}$ for $2 \mathrm{~h}$. Unoccupied sites on the nitrocellulose membranes were blocked by a 30 min incubation in TBS- $3 \%$ BSA at room temperature with agitation. The membranes were then successively incubated overnight at room temperature with hybridoma supernatants diluted 1 in 2 or ascitic fluid diluted 1 in 100 in Tw-TBS- $1 \%$ BSA, $1 \mathrm{~h}$ with RAM and $1 \mathrm{~h}$ with peroxidase-conjugated protein $A$, diluted 1 in 250 and 1 in 1000 , respectively, in the same buffer. Washings between incubation periods were performed with Tw-TBS. After two washings in Tw-TBS and two washings in TBS, the blots were developed by incubation at room temperature in TBS containing 0.06\% (w/v) 4-chloro-1-naphthol (Bio$\mathrm{Rad}$ ) and $5 \mathrm{mM}-\mathrm{H}_{2} \mathrm{O}_{2}$. The reaction was stopped by washing in distilled water.

$m A b$ isotypes. These were determined by direct latex agglutination immunoassay of the culture supernatants. Latex particles were coated with rat monoclonal anti-mouse IgG1, IgG2a, IgG2b, IgG3, IgM and polyclonal anti-mouse IgA according to a protocol similar to those described by Limet et al. (1988).

\section{Results}

\section{Monoclonal antibodies}

Twenty-two O-chain-specific mAbs were generated by fusion of spleen cells from mice infected with the rough B. melitensis strain B115 with the NSO myeloma. OPS specificity was determined by ELISA using OPS preparations of B. abortus 99 and B. melitensis $16 \mathrm{M}$ and by immunoblot using proteinase-K-digested S-LPS preparations. One of these mAbs, designated $12 \mathrm{G12}$, was subcloned and characterized by ELISA and immunoblotting to be further used for immunoelectron microscopy. According to its reactivity in ELISA with OPS and S-LPS of B. abortus 99 (A dominant) and $B$. melitensis $16 \mathrm{M}$ (M dominant) and the absence of reaction with R-LPS, mAb $12 \mathrm{G} 12$ recognized the OPS of both SLPS types (Table 1). Immunoblotting using this $\mathrm{mAb}$ on proteinase-K-digested S-LPS (not shown), on S-LPS prepared by the phenol/water method and on an R-LPS preparation confirmed the ELISA results (see Fig. 4).

According to its reactivity with purified R-LPS in ELISA (Table 1) and immunoblotting (Fig. 4), mAb A68/03F03/D05 was specific for R-LPS. The weak reactivity of this $\mathrm{mAb}$ with S-LPS preparations in 
Table 1. ELISA binding of the anti-S-LPS $m A$ b $12 G 12$ and the anti-R-LPS $m A b$ $A / 6803$ F03/DO5 to S-LPS and OPS from B. abortus 99 ( $A$ dominant) and B. melitensis $16 M$ ( $M$ dominant), and to $B$. melitensis B115 bacteria and fractions

The values reported represent the absorbance value of a $1 / 2$ hybridoma supernatant dilution after subtraction of the blank value.

\begin{tabular}{|c|c|c|c|c|c|c|c|c|c|}
\hline \multirow[b]{3}{*}{$\mathrm{mAb}$} & \multirow[b]{3}{*}{ Isotype } & \multicolumn{4}{|c|}{ ELISA against } & & & & \\
\hline & & \multicolumn{2}{|c|}{ S-LPS } & \multicolumn{2}{|c|}{ OPS } & \multicolumn{4}{|c|}{ ELISA against $B$. melitensis $B 115$} \\
\hline & & 99 & $16 \mathrm{M}$ & 99 & $16 \mathrm{M}$ & CE & $\mathrm{CW}$ & R-LPS & Bacteria \\
\hline $\begin{array}{l}\text { 12G12 } \\
\text { (S-LPS specific) }\end{array}$ & IgGl & $2 \cdot 010$ & $2 \cdot 278$ & $2 \cdot 317$ & $2 \cdot 080$ & 1.686 & 1.883 & 0.080 & 0.042 \\
\hline $\begin{array}{l}\text { A68/03F03/D05 } \\
\text { (R-LPS specific) }\end{array}$ & $\operatorname{IgG} 2 b$ & $1 \cdot 150$ & 0.623 & 0.017 & 0.259 & $1 \cdot 409$ & $1 \cdot 864$ & $1 \cdot 865$ & 0.992 \\
\hline
\end{tabular}

ELISA (Table 1) was due to the presence of R-LPS molecules in the preparations (as also observed in Fig. 4).

\section{ELISA}

Binding of anti-S-LPS mAb $12 \mathrm{G} 12$ to CE, CW, R-LPS and whole bacteria of $B$. melitensis B115 was compared with the binding of the anti-R-LPS $\mathrm{mAb}$ A68/03F03/D05 (Table 1). Binding to CE and CW was observed for both mAbs. Binding to R-LPS was only observed for the R-LPS-specific mAb. In contrast to the R-LPS-specific mAb, the S-LPS-specific mAb did not bind to whole bacteria of $B$. melitensis $\mathrm{B} 115$, which confirms the rough phenotype of this strain. These results indicate that $\mathrm{O}$-chain is present in this rough strain but that it is not exposed on the cell surface.

\section{Whole-mount immunogold labelling}

Immunogold labelling of whole $B$. melitensis B115 bacteria confirmed the absence of $\mathrm{O}$-chain exposure on the cell surface: immunogold labelling was observed with the R-LPS-specific mAb A68/03F03/D05 but not with the S-LPS-specific mAb 12G12 (Fig. 1).

\section{Section immunogold labelling}

Immunogold labelling of sections of $B$. melitensis $\mathrm{B} 115$ cells using the S-LPS-specific mAb 12G12 revealed the presence of $\mathrm{O}$-chain in the cytoplasm and at the periphery of the cytoplasm, probably at the cytoplasmic membrane (Fig. 2). No immunogold labelling was observed at the outer membrane by using this mAb. In some cells labelling was observed as clusters in the cytoplasm close to the cytoplasmic membrane (Fig. $2 b$ ), but in most of the cells immunogold labelling was dispersed in the cytoplasm. Immunogold labelling using the anti-R-LPS mAb A68/03F03/D05 was observed in the cytoplasm, near the cytoplasmic membrane and at the outer membrane, and outside the cells on R-LPS vesicles (Fig. 2c). No immunogold labelling was observed with a negative control mAb (Fig. $2 d$ ).

Immunogold labelling of $B$. melitensis $B 115 \mathrm{CW}$ sections with the anti-S-LPS mAb 12G12 was performed before sectioning (Fig. $3 a$ ). The vesicles derived from the outer membrane were not labelled. Labelling was observed on filamentous structures probably derived from the cytoplasmic membrane and on electron-dense amorphous aggregates clearly different from the vesicular structure. These electron-dense aggregates were also observed inside the outer-membrane vesicles but were not labelled since labelling with the anti-S-LPS mAb was performed before sectioning and consequently antibodies had no access to cytoplasmic structures inside the outer-membrane vesicle. No labelling was observed with a negative control mAb (Fig. $3 b$ ).

\section{Immunoblotting of B. melitensis B115 LPS}

B. melitensis $\mathrm{B} 115 \mathrm{CW}, \mathrm{CE}, \mathrm{CP}$ and R-LPS fractions were analysed by immunoblotting after SDS-PAGE (Fig. 4). The S-LPS-specific mAb $12 \mathrm{G} 12$ revealed bands in $\mathrm{CE}, \mathrm{CW}$ and $\mathrm{CP}$ ranging from 30 to $43 \mathrm{kDa}$ which were not revealed by the R-LPS specific $\mathrm{mAb}$ $\mathrm{A68} / 03 \mathrm{~F} 03 / \mathrm{D} 05$. The latter $\mathrm{mAb}$ revealed bands of lower molecular mass, below $21 \mathrm{kDa}$. The S-LPS-specific mAb $12 \mathrm{G} 12$ did not react with the $B$. melitensis B115 R-LPS fraction (lane 4) extracted according to the procedure of Galanos et al. (1969), which corresponds to R-LPS of the cell surface.

Proteinase-K-digested S-LPS fraction from B. melitensis $\mathrm{B} 115 \mathrm{CW}$ showed the same molecular mass as 

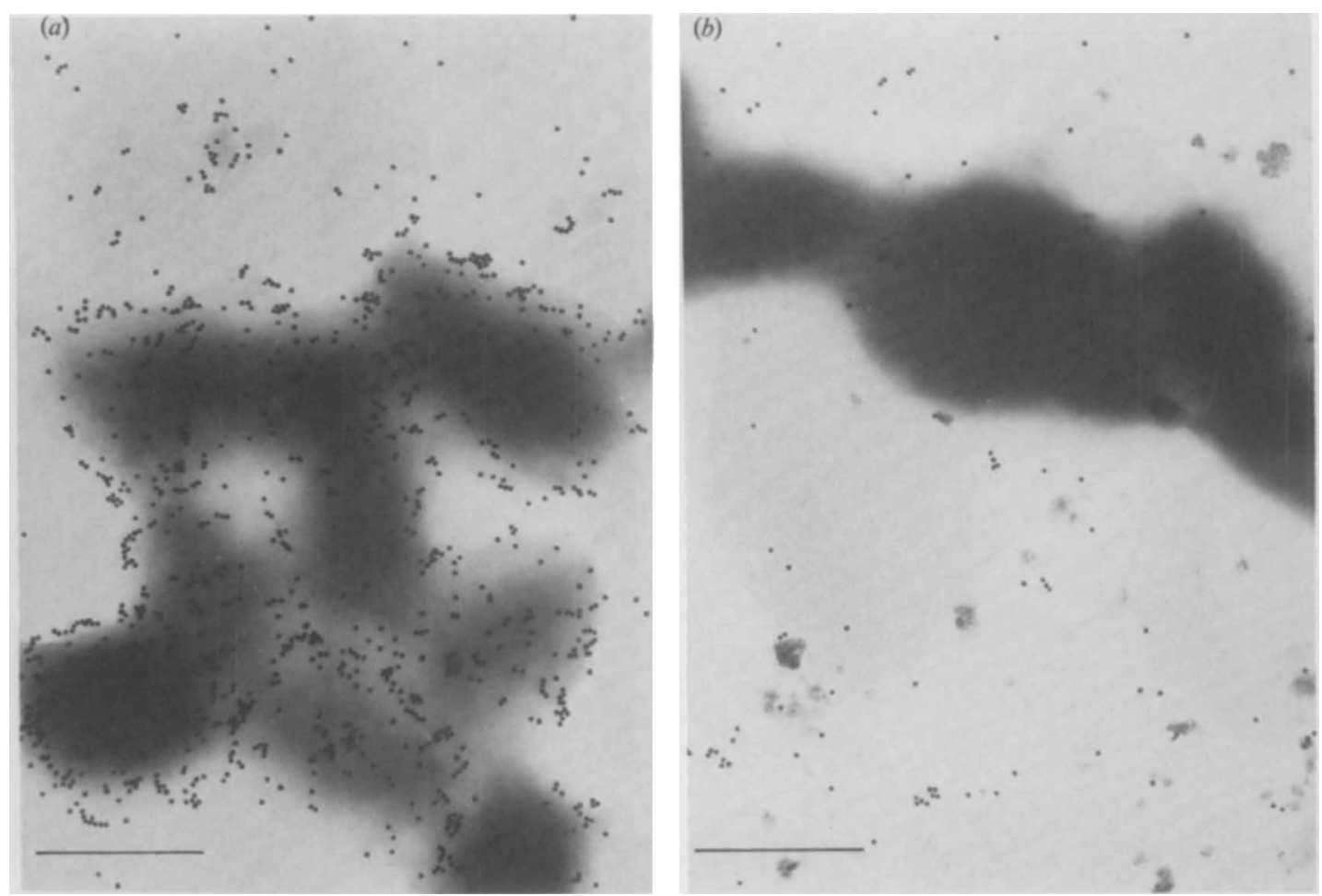

Fig. 1. Immunogold labelling of whole cells of $B$. melitensis B115 with anti-R-LPS mAb A68/03F03/D05 (a) and anti-S-LPS mAb 12G12 (b). Bars, $0 \cdot 5 \mu \mathrm{m}$.

proteinase-K digested S-LPS fraction from $B$. abortus 99 and $B$. melitensis $16 \mathrm{M}$ (not shown).

\section{Discussion}

The present study reports the O-chain expression and its localization in the B. melitensis B115 rough strain which is commonly used for cytoplasmic antigen extraction (Jones et al., 1973; Zygmunt et al., 1990) and for polysaccharide B extraction (Diaz et al., 1972, 1983, 1979; Moreno et al., 1981). The interest of using B. melitensis B115 was that it was believed to be devoid of S-LPS or O-chain since this strain is considered as a rough strain by classical criteria (Alton et al., 1988).

We obtained 22 OPS-specific mAbs by fusion of spleen cells of mice infected with $B$. melitensis strain B115 with the NSO myeloma, suggesting expression of immunogenically active O-chain in this strain. Most of the mAbs recognized epitopes common to both $A$ and M S-LPS types (data not shown). mAbs to S-LPS of Brucella spp. have already been reported with specificity for common epitopes and cross-reacting or not with Y. enterocolitica 0:9 S-LPS (Palmer \& Douglas, 1989).
As shown by ELISA the anti-S-LPS mAb $12 \mathrm{G} 12$ did not bind to whole $B$. melitensis B115 cells but it bound well to $\mathrm{CE}$ or $\mathrm{CW}$ of this strain. The $\mathrm{mAb}$ specific for $\mathrm{R}-$ LPS bound to whole bacterial cells as well as to CE or $\mathrm{CW}$. Thus this rough strain expresses $\mathrm{O}$-chain but the latter is not exposed at the cell surface. This is also confirmed by the fact that mAb 12G12 did not react with the $B$. melitensis B115 R-LPS fraction prepared from whole bacterial cells by the phenol/water/chloroform/ light petroleum method of Galanos et al. (1969). This method leaves the bacterial cells morphologically intact as shown by electron microscopy (Dubray, 1981). Therefore R-LPS extracted by this method is probably only the cell-surface-exposed R-LPS; this may explain why Jones et al. (1973) were unable to extract S-LPS from B. melitensis B115. Thus, rabbits immunized with R-LPS prepared from $B$. melitensis B115 by the method of Galanos et al. (1969) produced agglutinins to rough brucellae only and precipitins to the $\mathbf{R}$ surface antigen only (Jones et al., 1973).

O-chain expression could be visualized by immunoelectron microscopy in thin sections of cells of $B$. melitensis B115. The localization of O-chain in this strain is mainly cytoplasmic. No immunogold labelling of the outer membrane was observed by using the S-LPS 

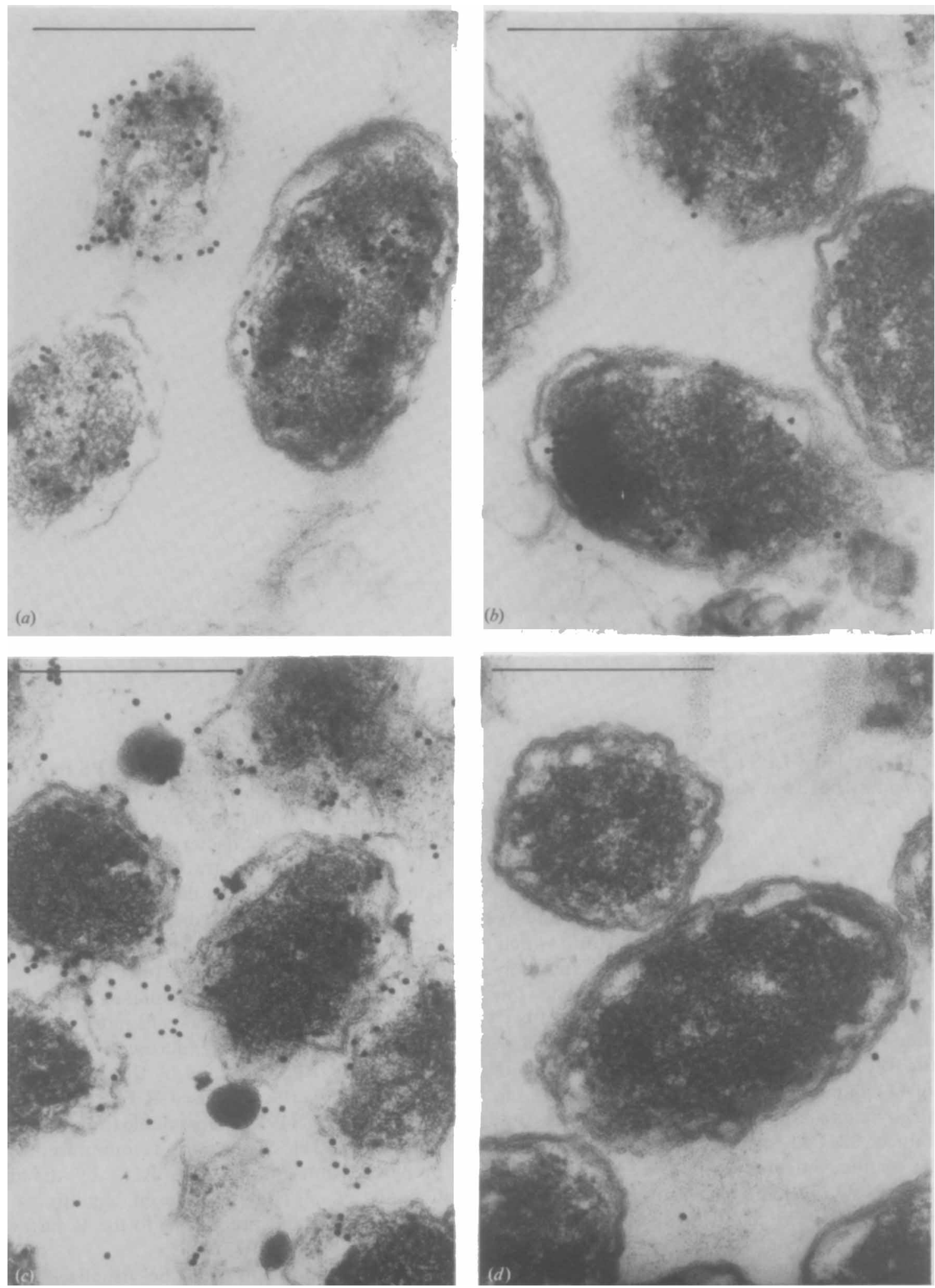

Fig. 2. Immunogold labelling of sections of $B$. melitensis B115 cells with anti-S-LPS mAb $12 \mathrm{G} 12(a, b)$, anti-R-LPS mAb A68/03F03/D05 (c) and negative control mAb $(d)$. Bars, $0 \cdot 5 \mu \mathrm{m}$. 

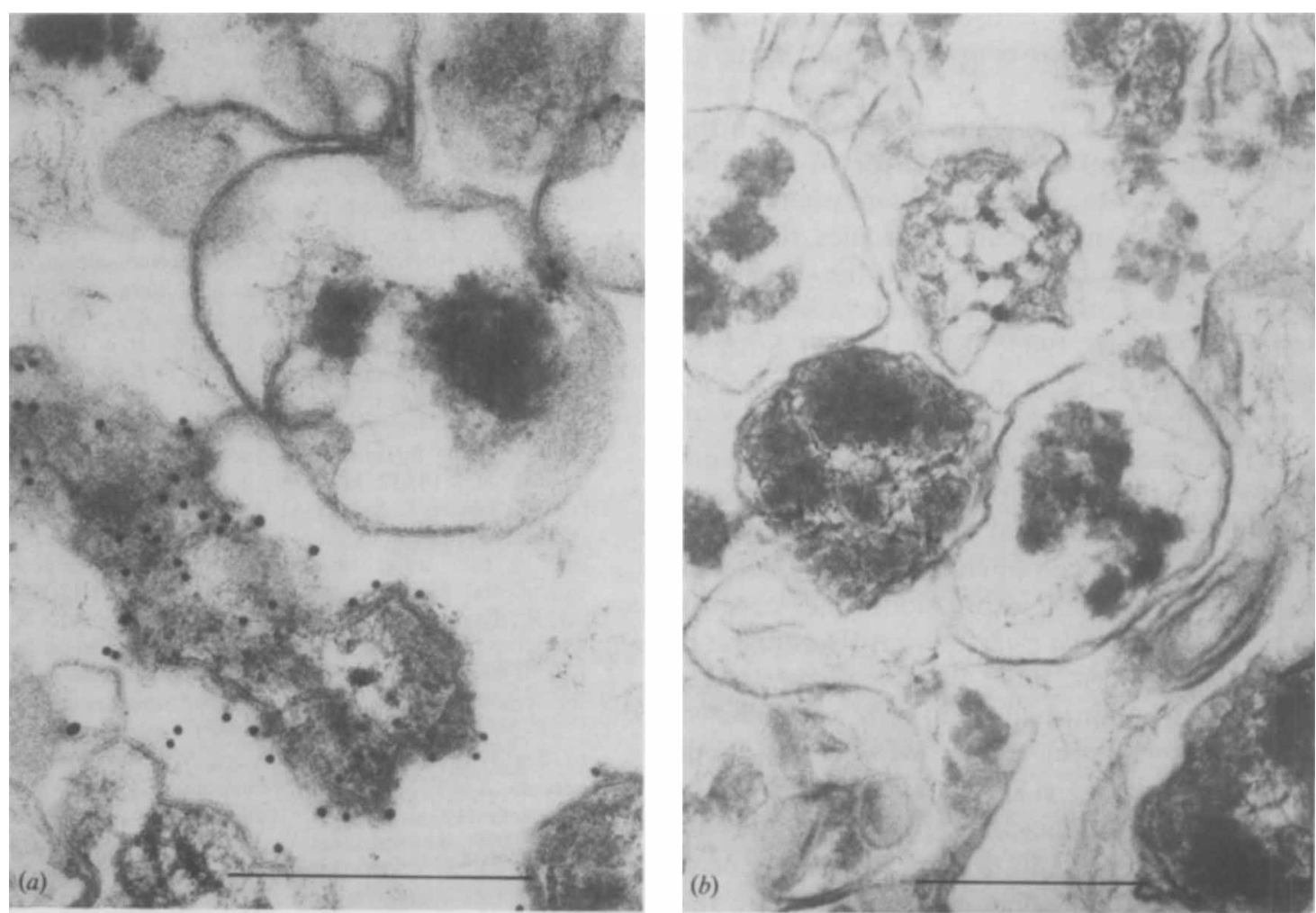

Fig. 3. Immunogold labelling of sections of $B$. melitensis $\mathrm{B} 115 \mathrm{CW}$ with anti-S-LPS $\mathrm{mAb} 12 \mathrm{G} 12(a)$ and negative control mAb $(b)$. Bars, $0 \cdot 5 \mu \mathrm{m}$.

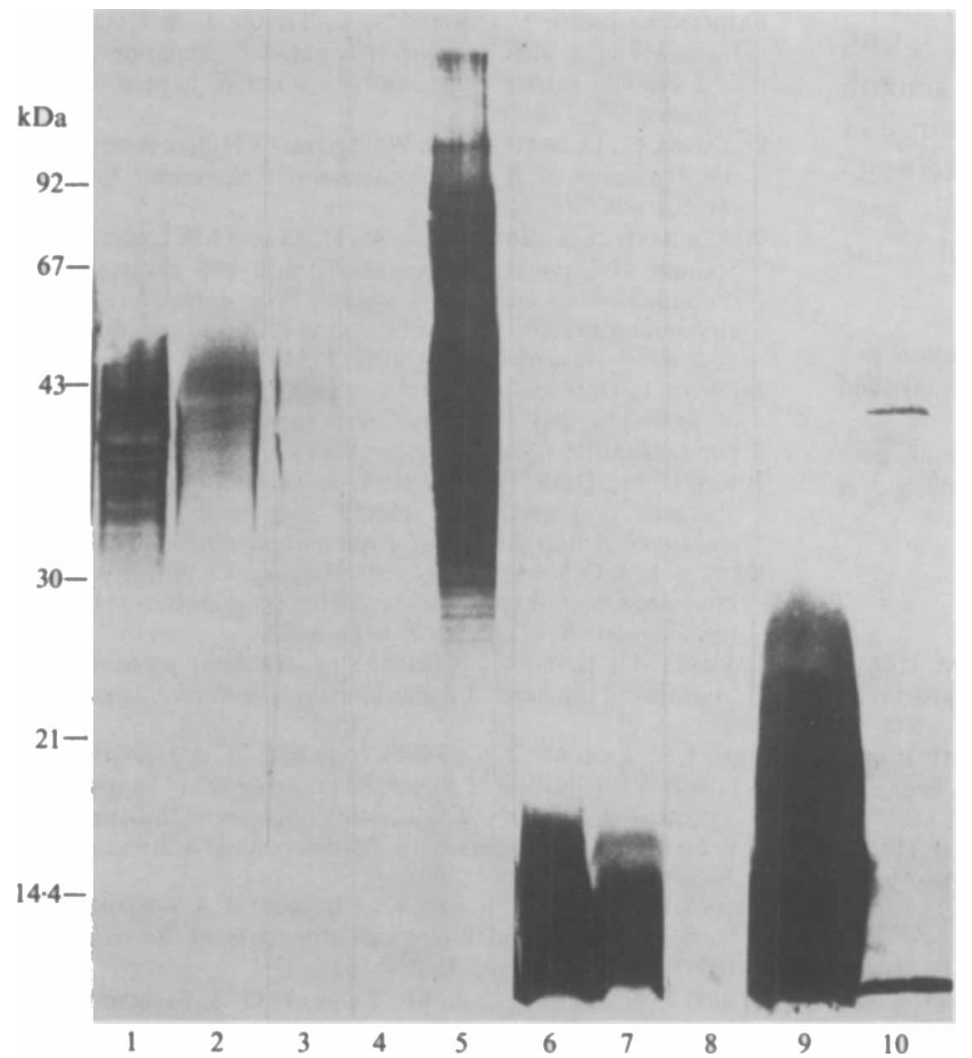

Fig. 4. Immunoblot of B. melitensis B115 CE $(125 \mu \mathrm{g})$

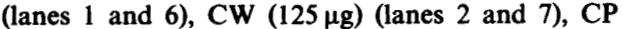
$(125 \mu \mathrm{g})$ (lanes 3 and 8), R-LPS (62.5 $\mu \mathrm{g}$ ) (lanes 4 and 9) and $B$. melitensis 16M S-LPS (phenol fraction) $(6.25 \mu \mathrm{g})$ (lanes 5 and 10) with anti-S-LPS $\mathrm{mAb}$ 12G12 (lanes 1, 2, 3, 4, 5) and anti-R-LPS $\mathrm{mAb}$ A68/03/F03/D05 (lanes 6, 7, 8, 9, 10). The positions of protein molecular mass markers are shown on the left. 
specific $\mathrm{mAb}$. In contrast the anti-R-LPS $\mathrm{mAb}$, a marker of the outer membrane, also bound to whole bacterial cells.

We do not know yet if the O-chain expressed in the cytoplasm is free or linked to R-LPS or to the lipid carrier. The transfer of the OPS to the core is a complex reaction between membrane-bound molecules, the undecaprenol-diphosphate-polysaccharide on the one hand, and the complete core on the other (Mäkelä \& Stocker, 1984; Mulford \& Osborn, 1983; Osborn, 1979). Since SLPS biosynthesis takes place in the cytoplasmic membrane, a part of the O-chain expressed in the rough $B$. melitensis B115 strain is probably linked to a lipid moiety: R-LPS or the undecaprenol-diphosphate-polysaccharide lipid carrier. Several hypotheses can be put forward to explain the rough phenotype of $B$. melitensis B115 despite its O-chain expression: the core is incomplete, as in Salmonella rfaK mutants (Beckmann et al., 1964; Kent \& Osborn, 1968; Lindberg et al., 1972; Weiner et al., 1965); unfinished $O$ units are not attached to the core in vivo (Yuasa et al., 1969); or, if both requirements are fulfilled (1) transfer of the O-chain from the undecaprenol-diphosphate-polysaccharide carrier to the core does not occur, or (2) translocation of SLPS molecules from the cytoplasmic membrane to the outer membrane does not occur.

The lipid-bound O-chain has been isolated from $B$. melitensis $\mathrm{B} 115 \mathrm{CW}$ as evidenced by SDS-PAGE and immunoblot analysis. Bands revealed by the anti-S-LPS $\mathrm{mAb} 12 \mathrm{G} 12$ have the same molecular size as S-LPS bands of $B$. melitensis $16 \mathrm{M}$ and $B$. abortus 99 smooth strains. To clearly identify the reason for the absence of OPS at the cell surface, high-molecular-mass proteinaseK-digested LPS from CW should be purified, acid hydrolysed and the lipid moiety analysed as well as the polysaccharide.

We are most grateful to J. M. Verger and M. Grayon for culture and control of bacterial strains. We thank G. Bézard, A. Van Rompaye and J. Van Broeck for expert technical assistance.

A. Cloeckaert was supported by the Institut National pour l'Encouragement de la Recherche Scientifique dans l'Industrie et l'Agriculture.

\section{References}

Alton, G. G., Jones, L. M., Angus, R. D. \& Verger, J. M. (1988). Techniques for the Brucellosis Laboratory. Paris: Institut National de la Recherche Agronomique.

Beckmann, I., Subbalah, T. V. \& Stocker, B. A. D. (1964). Rough mutants of Salmonella typhimurium. 2. Serological and chemical investigations. Nature, Lodon 1, 1299-1301.

Bundle, D. R., Cherwonogrodzky, J. W. \& PerRy, M. B. (1987). The structure of the lipopolysaccharide $\mathrm{O}$-chain ( $\mathrm{M}$ antigen) and polysaccharide B produced by Brucella melitensis 16M. FEBS Letters 216, 261-264.

Bundle, D. R., Cherwonogrodzky, J. W. \& Perry, M. B. (1988). Characterization of Brucella polysaccharide B. Infection and Immunity 56, 1101-1106.
Bundle, D. R., Cherwonogrodzky, J. W., Gidney, M. A. J., Meikle, P. J., Perry, M. B. \& Peters, T. (1989). Definition of Brucella $\mathbf{A}$ and $\mathbf{M}$ epitopes by monoclonal typing reagents and synthetic oligosaccharides. Infection and Immunity 57, 2829-2836.

Cloeckaert, A., de Wergifosse, P., Dubray, G. \& Limet, J. N (1990). Identification of seven surface-exposed Brucella outer membrane proteins by use of monoclonal antibodies: immunogold labeling for electron microscopy and enzyme-linked immunosorbent assay. Infection and Immunity 58, 3980-3987.

Diaz, R. \& Levieux, D. (1972). Respective role in the serology of bovine brucellosis of antigens and immunoglobulins. Comptes Rendus de l'Academie des Sciences Paris 274, 1593-1596.

Diaz, R., Jones, L. M., LeONG, D. \& Wilson, J. B. (1968). Surface antigens of smooth Brucellae. Journal of Bacteriology 96, 893-901.

Diaz, R., Garatea, P., Jones, L. M. \& Moriyon, I. (1979). Radial immunodiffusion test with a Brucella polysaccharide antigen for differentiating infected from vaccinated cattle. Journal of Clinical Microbiology 10, 37-41.

Diaz, R., Toyos, J., Salvo, M. D. \& Pardo, M. L. (1981). A simple method for the extraction of polysaccharide B from Brucella cells for use in the radial immunodiffusion test diagnosis of bovine brucellosis. Annales de Recherches Vétérinaires 12, 35-39.

Diaz, R., Toyos, J., Salvo, M. D., Fernandez-Lago, L., Alonso, B. Moriyon, I. \& Dorronsoro, I. (1983). Studies on the polysaccharide $B$ and native hapten of Brucella and Yersinia enterocolitica serotype 9. Developments in Biological Standardization 56, 213-220.

Douglas, J. T. \& Palmer, D. A. (1988). Use of monoclonal antibodies to identify the distribution of $\mathrm{A}$ and $\mathrm{M}$ epitopes on smooth Brucella species. Journal of Clinical Microbiology 26, 1353-1356.

DUBRAY, G. (1981). Etude ultrastructurale et biochimique des enveloppes des bactéries du genre Brucella. PhD thesis, Université de Paris-Sud.

Dubray, G. \& Charriaut, C. (1983). Evidence of three major polypeptide species and two major polysaccharide species in the Brucella outer membrane. Annales de Recherches Vétérinaires 14, 311-318.

Dubray, G. \& LIMET, J. (1987). Evidence of heterogeneity of lipopolysaccharides among Brucella biovars in relation to $\mathrm{A}$ and $\mathbf{M}$ specificities. Annales de l'Institut Pasteur/Microbiologie 138, 27-37.

Fernandez-Lago, L., Moriyon, I., Toyos, J. \& Diaz, R. (1982). Immunological identity of Brucella native hapten, polysaccharide B, and Yersinia enterocolitica serotype 9 native hapten. Infection and Immunity 38, 778-780.

Galanos, C., Luderitz, O. \& WestPhal, O. (1969). A new method for the extraction of R-lipopolysaccharides. European Journal of Biochemistry 9, 245-249.

Garin-Bastuji, B., Bowden, R. A., Dubray, G. \& Limet, J. N. (1990). Sodium dodecyl sulfate-polyacrylamide gel electrophoresis and immunoblotting analysis of smooth-lipopolysaccharide heterogeneity among Brucella biovars related to $\mathbf{A}$ and $\mathbf{M}$ specificities. Journal of Clinical Microbiology 28, 2169-2174.

JACQUES, I., OLIVIER-BERNARDin, V. \& DUBRAY, G. (1991). Induction of antibody and protective responses in mice by Brucella Opolysaccharide-BSA conjugate. Vaccine 9, 896-900.

Jones, L. M., DiAz, R. \& TAYLOR, A. G. (1973). Characterization of allergens prepared from smooth and rough strains of Brucella melitensis. British Journal of Experimental Pathology 54, 492-508.

KENT, J. L. \& OSBORN, M. J. (1968). Haptenic O-antigen as a polymeric intermediate of in vivo synthesis of lipopolysaccharide by Salmonella typhimurium. Biochemistry 7, 4419-4422.

LAEMMLI, U. K. (1970). Cleavage of structural proteins during the assembly of the head of bacteriophage T4. Nature, London 227,680 685.

Lam, J. S., Lam, M. Y. C., MacDonald, L. A. \& Hancock, R. E. W. (1987). Visualisation of Pseudomonas aeruginosa $\mathrm{O}$ antigens by using a protein A-dextran-colloidal gold conjugate with both immunoglobulin $\mathbf{G}$ and immunoglobulin $\mathbf{M}$ monoclonal antibodies. Journal of Bacteriology 169, 3531-3538.

Leong, D., Diaz, R., Milner, K., Rudbach, J. \& Wilson, J. B. (1970). Some structural and biological properties of Brucella endotoxin. Infection and Immunity 1, 174-182.

Limet, J. N., Plommet, A. M., Dubray, G. \& Plommet, M. (1987). Immunity conferred to mice by anti-LPS monoclonal antibodies in 
murine brucellosis. Annales de l'Institut Pasteur/Immunologie 138, 417-424.

Limet, J. N., Berbinschi, A., Cloeckaert, A., Cambiaso, C. L. \& Masson, P. L. (1988). Longitudinal study of brucellosis in mice by immunoassay of lipopolysaccharide-related antigens in blood and urine. Journal of Medical Microbiology 26, 37-45.

Lindberg, A. A., Holme, T., Hellerqvist, C. G. \& Svensson, S. (1972). Studies of a Li-hapten isolated from cell-walls of the rough mutant Salmonella typhimurium 395 MR10. Acta Pathologica et Microbiologica Scandinavica B80, 743-750.

MÄKELÄ, P. H. \& STOCKER, B. A. D. (1984). Genetics of lipopolysaccharide. In Handbook of Endotoxin, vol. 1, Chemistry of Endotoxin, pp. 59-137. Edited by E. T. Rietschel. Amsterdam: Elsevier.

Meikle, P. J., Perry, M. B., Cherwonogrodzky, J. W. \& Bundle, D. R. (1989). Fine structure of $A$ and $M$ antigens from Brucella biovars. Infection and Immunity 57, 2820-2828.

Moreno, E., Speth, S. L., Jones, L. M. \& Berman, D. T. (1981). Immunochemical characterization of Brucella lipopolysaccharides and polysaccharides. Infection and Immunity 31, 214-222.

MUlford, C. A. \& OSBORN, M. J. (1983). An intermediate step in translocation of lipopolysaccharide to the outer membrane of Salmonella typhimurium. Proceedings of the National Academy of Sciences of the United States of America 80, 1159-1163.

NAKANE, P. K. \& KaWAOÏ, A. (1974). Peroxidase-labelled antibody, a new method of conjugation. Journal of Histochemistry and Cytochemistry 22, 1084-1091.

OSBORN, M. J. (1979). Biosynthesis and assembly of lipopolysaccharide of the outer membrane. In Bacterial Outer Membranes, pp. 15-34. Edited by M. Inouye. New York: Wiley.
Palmer, D. A. \& Douglas, J. T. (1989). Analysis of Brucella lipopolysaccharide with specific and cross-reacting monoclonal antibodies. Journal of Clinical Microbiology 27, 2331-2337.

Voller, A., Bidwell, D. E. \& Bartlett, A. (1979). The Enzyme Linked Immunosorbent Assay (ELISA). Guernsey: Dynatech Europe.

Weiner, I. M., Higuchi, T., Rothfield, L., SAltMarsh-ANDrew, M., OSBORN, M. J. \& HORECKER, B. L. (1965). Biosynthesis of bacterial lipopolysaccharide. V. Lipid-linked intermediates in the biosynthesis of the O-antigen groups of Salmonella typhimurium. Proceedings of the National Academy of Sciences of the United States of America 54, 228-235.

Wilson, G. S. \& Miles, A. A. (1932). The serological differentiation of smooth strains of the Brucella group. British Journal of Experimental Pathology 13, 1-13.

Yuasa, R., LeVinthal, M. \& Nikaido, H. (1969). Biosynthesis of cell wall lipopolysaccharide in mutants of Salmonella. Journal of Bacteriology 100, 433-444.

Zygmunt, M. S., Dubray, G., Bundee, D. R. \& Perry, M. B. (1988). Purified native haptens of Brucella abortus B19 and B. melitensis 16M reveal the lipopolysaccharide origin of the antigens. Annales de l'Institut Pasteur/Microbiologie 139, 421-433.

Zygmunt, M. S., Martin, J. C. \& Dubray, G. (1990). Analysis of immune response: comparison of immunoblots after isoelectric focusing and sodium dodecyl sulfate-polyacrylamide gel electrophoresis using cytoplasmic protein extract from Brucella. FEMS Microbiology Letters 70, 263-268. 